\title{
CoRPORATE GOVERNANCE PRACTICES AT SOUTH AFRICAN HIGHER EDUCATION INSTITUTIONS: AN ANNUAL REPORT DISCLOSURE ANALYSIS
}

\author{
Karen Barac* \\ University of South Africa \\ barack@unisa.ac.za \\ Ben Marx+ \\ Tankiso Moloi\# \\ University of Johannesburg \\ University of South Africa \\ benm@uj.ac.za \\ tankisomoloi@webmail.co.za
}

May 2011

\begin{abstract}
Higher education institutions are presently facing many challenges, ranging from economic and financial constraints to social and educational issues. Accordingly, sound management and governance are essential, and this brings the governance model of $\mathrm{HEls}$ more in line with business corporations. This article provides an overview of the state of governance practices at higher education institutions in South Africa, and an assessment of the corporate governance disclosures in their annual reports. This was done through a literature review of higher education developments, including a South African perspective, supported by empirical evidence obtained from assessing the annual reports of these institutions. The study found that, although most of these institutions are providing disclosure on their corporate governance structures and practices in line with the recommendations of the Higher Education Act and King II, such disclosure is often lacking in detail and could be improved.
\end{abstract}

\section{Keywords}

Corporate governance, higher education, higher education institutions, University councils, University council committees, annual report disclosures, higher education governance

\footnotetext{
* Prof Karen Barac is professor and head of school, at the School of Accounting, University of South Africa, South Africa.

+ Prof Ben Marx is professor and head of auditing at the Department of Accountancy, University of Johannesburg, South Africa.

\# Mr Tankiso Moloi is a doctoral candidate, Department of Financial Accounting, University of South Africa, Pretoria, South Africa.
} 


\section{INTRODUCTION}

Corporate governance can be described as the system by which entities are directed and controlled. This definition was formulated by the Cadbury Report on Corporate Governance in the United Kingdom as far back as 1992 (Cadbury, 1992), and, although refined over the years, the term corporate governance still remains variously defined (Goedegebuure \& Hayden, 2007). Davis (2005), for example, describes it as the structures, processes and institutions within and around organisations that allocate power and resource control among participants for which they will be held accountable. In the context of higher education, corporate governance refers to all processes and institutions that rule the division and management of power (making decisions that are binding on others) inside higher education institutions (HEls) and national university systems (Lazaretti \& Tavoletti, 2006).

The higher education environment has become more demanding over the years, resulting in $\mathrm{HEls}$ currently facing many challenges, which include the lack of student preparedness due to inadequate school education, institutional capacity constraints, increased emphasis on research, quality assurance expectations, globalisation, rapid development in information technology, the quest for market orientation and customer centred-operations, increasingly complex legal environments, funding and resources constraints, as well as the growth in the local and international providers of private higher education (Council for Higher Education (CHE), 2009a; CHE, 2009b; CHE, 2009c; De Groof, Neave \& Svec, 1998; Kezar \& Eckel, 2004; Marx, 2007; Mills, 2007; Peterson, 1986; Pope, 2004; Republic of South Africa (RSA), 2007; Salter,\& Tapper, 2002). Even within such a complex environment public HEls carry substantial economic weight (Küpper, 2003) and are fulfilling many occupational roles that involve various stakeholders.

Traditionally, universities or HEls were governed by means of the collegial model, embodying the philosophy of self-governance with little or no direct government interference (Harman \& Treadgold, 2007). Over the past few decades there has been a move away from this selfgovernance model to a model more closely aligned with business corporations (Lazaretti \& Tavoletti, 2006). The initial paradigm for managing HEls by means of state policy-making and implementation has now been extended to include a more cooperative method of governing, where the state and non-state actors participate in mixed networks (Enders, 2004). According to Mok (2003:119), this movement has changed the role of HEls: they now act less as critics of society and more as servants responding to the needs of society, being at a crossroads between the "alleged democracy of a whimsical collegiality and the problematic efficiency of hardnosed managerialism".

Governments throughout the world have thus in recent years sought to achieve alignment of accountability and control over higher education by delegating to $\mathrm{HEl}$ s increased authority over their inputs and resource use, while increasing accountability for outputs and performance (Hall, Symes \& Luescher, 2002). New responsibilities added to HEls require sound management, effective leadership, and strong governance structures for effective and efficient management (Geuna \& Muscio, 2009; Marx, 2007; Kezar \& Eckel, 2004; Bargh, Scott \& Smith, 1996).

Annual report disclosure of information on governance is pertinent to investors' decisionmaking as well as stakeholders' interests (Ponnu \& Ramthandin, 2008). Skærbæk (2005) believes that annual reports lend legitimacy to an organisation, mainly for external readers and audiences, while Doost (1998) maintains that for HEls such information should be disseminated to the general public and affected constituents who make judgements in terms of cost and 
service delivery. Steccolini (2004), however, questions whether the annual reports of public institutions could be regarded as an accountability medium. While supporting the idea that annual reports should be directed to both internal and external stakeholders, Steccolini (2004) believes that annual reports as a medium for the accountability of public institutions should be researched further. In his research on a large Danish business university's reporting practices, Skærbæk (2005) demonstrated that the management of this HEl utilises its annual report not as information for decision-making, but rather "for impression management purposes".

Very little research on the governance of HEls in South Africa exists. Marx (2007), benchmarked the basic governance-regulatory requirements of South African $H E l s$ against corporate governance principles and practices, and concluded that although HEls' councils appear to be well established, their corporate governance disclosures need to be improved. Arnold (2006) focused attention on the reporting of South African $\mathrm{HEls}$ by researching university sustainability through decision-orientated financial reporting, and found that financial reports constitute the major medium of financial accountability through which $\mathrm{HEls}$ render an account of their performance in fulfilment of their responsibilities.

\section{OBJECTIVES, SCOPE AND LIMITATIONS}

The objectives of this article are twofold. Firstly, it provides a brief overview of the state of governance practices of $\mathrm{HEls}$ in South Africa by reviewing international higher education governance changes and placing these it in the context of current literature on HEls' governance developments in South Africa. Secondly, it assesses the corporate governance disclosures in the 2009 annual reports of the 23 public HEls in South Africa against the requirements of the Higher Education Act 101 of 1997 (RSA, 1997), the Regulations of the Act of 2003 and 2007 (RSA, 2003; 2007) and the Implementation Manual for Annual Reporting by Higher Education Institutions issued by the Department of Higher Education and Training under the regulations of the Act (Department of Education (DOE), 2007).

The study has specific limitations. The assessment is limited to the published annual reports of the 22 public HEls in South Africa, which had been submitted to the Department of Higher Education and Training (DoHET) for 2009 (these reports had to be submitted by 30 June 2010). One public HEl had not submitted its annual report to the DoHET, and was therefore excluded from the study. Private HEls operating within the South African higher education environment did not form part of the study, and represent a research area to explore in future. The justification for limiting this study to the public HEls' governance disclosures in their submitted annual reports is that these represent the official reports that $H E l$ s are liable to submit to the DoHET (RSA, 1997). An investigation during the second half of 2010 revealed that the annual reports of only 11 of the 23 South African HEls were available on their websites and therefore the researchers' reviews were limited to the hard copies of the submitted annual reports obtained directly from the Council of Higher Education in January 2011.

There are also limitations inherent in the contents analysis technique that was used to assess the annual reports of the 22 South African public HEls. Even though the content analysis technique has limitations, as noted by Unerman (2000), recent literature still supports content analysis as an acceptable research method for analysing annual reports, because the technique is particularly useful for extracting information that is not explicitly presented in a quantified and structured format, but is implicit in the text (Abeysekera, 2007; Barac \& Moloi, 2010; Brennan \& Solomon, 2008; Boesso \& Kumar, 2007). 
The remainder of this article is arranged as follows: the next section presents an overview of recent changes in the governance of $\mathrm{HEls}$, with an emphasis on the South African perspective. Then the methodology followed in this study is outlined, and this is followed by a section reporting on the findings that resulted from the assessment of corporate governance disclosures in the 22 South African public HEls' annual reports. In the final section the results are summarised, and conclusions and recommendations are made.

\section{THEORETICAL BACKGROUND}

\subsection{Recent developments of corporate governance in higher education}

$H \varepsilon l s$ are unique entities operating in an ever-changing educational landscape and are faced with many challenges in meeting their core responsibilities of teaching and research. Daniel Tarschys, Secretary General of the Council in Europe, described the extraordinary character of universities as follows: "the university is in origin and to a considerable extent remains, a mediaeval corporation: that is to say, a private association recognised by the state as pursuing a public purpose. In practice, European countries, east and west, strive for the difficult balance between autonomy and accountability" (De Groof et al., 1998).

The importance of sound governance at $\mathrm{HEls}$ as a means of realising institutional goals by regulating their internal affairs accordingly (Salter \& Tapper, 2002) has grown over the years (Kennedy 2003). Bargh et al. (1996) attribute the emphasis placed on higher education governance during the last number of decades to, firstly, rising activism that has questioned the legitimacy of university councils and governing bodies, and, secondly, to the pressures of massification and marketisation, which have tilted the balance of university business away from 'internal', essentially academic issues to 'external' issues concerning institutional positioning, mission and even survival.

Vaira (2004) identifies additional factors contributing to the emphasis on HEls' governance, namely: the reduction in state endowment, $\mathrm{HEls}$ obtaining more institutional, organisational and financial autonomy, the growing requirement to pursue and improve quality, effectiveness, efficiency and responsiveness in all the strategic higher education activities as well as increased socially and politically acountability. Shattock (2004) elaborates on the advances of sound $\mathrm{HEl}$ corporate governance by claiming that it alleviates pressures and improves effectiveness contributing to improved performance and reducing the possibility of malpractice or simply misgovernance.

Initially a traditional or collegial model of governance in higher education was followed, focusing on self-governance and with little or no direct government interference (except for the indirect influence of ministerial appointees) (Harman \& Treadgold, 2007). Following the increased expectations of governments, society, students and staff for higher education (Newby, 2003), the governance in HEls gained more emphasis, resulting in a move away from the traditional governance model to a model closely aligned with business corporations. This move largely reflects the belief that the "corporate"-aligned governance model will assure greater efficiency/transparency and accountability in managing financial and human resources. Henkel (1997) holds that this move is justified, arguing that higher education is provided largely through public money, and affects the interests of multiple stakeholders in society. The academic profession should therefore be called to public account. 
The abovementioned reform initiatives required a commitment to more managerial modes of operation in HEls and ostensibly led to increased accountability and reporting (Mir \& Rahaman, 2003).

\subsubsection{International perspective}

In an attempt to improve governance in $\mathrm{HEls}$, the higher education landscape worldwide has been subjected to a continuous process of reorganisation and change over the last number of decades. Geuna and Muscio (2009) found that these re-organisations started in the United Kingdom, and spread to Europe, beginning with the Netherlands and the Scandinavian countries, and more recently to countries such as France and Italy. They found that universities have been transformed from small, elite institutions, managed by academic peers in a collegial way, into large multi-task organisations, and that this requires new governance structures to manage all the tasks and roles of today's institutions (Geuna \& Muscio, 2009).

There is an extensive body of knowledge on the reform of higher education to promote transparency and accountability. Taylor (2003), for example, explains that the period since 1979 has witnessed radical changes in England's higher education, including the introduction of new instruments for accountability and audit, a reduction in government funding and an increasing diversity of funding sources. The Jarratt Report in 1985 and the Report of the National Advisory Body of 1987 advanced the idea of a university as a corporate enterprise, stressing the authority of university councils and the role of the vice-chancellor as chief executive (Middlehurst 2004; Taylor, 2003; Henkel, 1997).

The idea of a university as a corporate enterprise therefore became well established in England, where entrepreneurial universities emerged with strong institutional management (Taylor, 2003). This can be ascribed to many factors, such as higher student numbers, the reduction in dependence on state funding, increased local and international competition, and demanding customers (Middelhurst, 2004).

The United States higher education system has also been reformed to ensure that it can cope with new environmental conditions such as constricted state resources, globalisation, increasing competition from for-profit education providers, the rapid development of information technology, and the quest for market orientation and 'customer-centred' operations (Lazzeretti \& Tavoletti, 2006). According to Huisman and Currie (2004), the United States higher education system has shifted from an internally orientated system of accountability towards being more externally orientated. It is noted, however, that practices in the United States vary: for example, some states opt for more centralised organisations, while others attempt to decentralise their systems (Mills, 2007).

Over recent years, Australian $\mathrm{H} \varepsilon \mathrm{ls}$ have also moved away from largely collegial to much more corporate styles of university management (Harman, 2002; Kennedy, 2003). Harman and Treadgold (2007) ascribe this to the decline in the confidence of the state in the self-governing models traditionally valued by universities The period between 1986 and 1996, when the number of enrolled higher education Australian students nearly doubled, led to the establishment of 'executive-centred governance' in an $\mathrm{HEl}$ system where strong support and incentives were provided to vice-chancellors to centralise authority and capture internal resources (Considine, 2000). Harman and Treadgold (2007) believe that the role of vice-chancellor becoming more managerial in nature, similar to that of a chief executive officer (CદO) in commerce, is a clear indication of the application of a new managerial governance model in Australian higher education. 
In Europe there has been a similar trend favouring managerialism over more collegial approaches to the management of higher education (Kennedy, 2003). De Boer and Goedebuure (2007), for example, claim that during the mid-eighties Dutch $\mathrm{HEls}$ became more autonomous by embracing the concept of institutional management. This was followed by the introduction of new legislation in 2006, which encouraged HEls to act as "public entrepreneurs", where groups with stakeholder interest in universities should play a more prominent role, thus establishing horizontal accountability in Dutch higher education (De Boer \& Goedebuure, 2007).

According to Belloc (2003) a similar trend is evident in France, where deliberate efforts are made to improve transparency in higher education, but the process is far from complete. Although French $\mathrm{HEls}$ are moving towards increasing autonomy, they are also subject to more frequent government monitoring (Huisman \& Currie, 2004), which Belloc (2003) regards as "both excessive and inadequate". Belloc (2003) advocates increased autonomy for French HEls and a real system of accountability to ensure management and decision-making accountability and to assess the ability of $\mathrm{HEls}$ to achieve the strategic objectives they have set themselves.

\subsubsection{South African perspective}

Early HEls in South Africa were based on models from United Kingdom and Scottish universities (Hall et al., 2002). Over the years these $\mathrm{HEls}$ have been subjected to political and socio-cultural pressures and developments that have played a role in the formation and structuring of the current South African higher education landscape. Another factor significantly influencing higher education in South Africa was early dissension as regards the medium of instruction, which led to a split between English-and Afrikaans-medium universities (Hall et al., 2002).

Hall et al. (2002) note that the language split was followed by sharp divisions along racial and ethnic lines, with the $36 \mathrm{HEls}$ being divided into sub-categories: four English-medium universities reserved for white students, six Afrikaans-medium universities reserved for white students, seven technikons reserved for white students, six universities and five technikons located in apartheid homelands and reserved for African students, two urban universities and two technikons reserved for Coloured and Indian students, two "special-purpose" institutions reserved for black students, and two distance-education providers (Hall et al., 2002:20).

Since 1994, however, the trend has been to realign and reintegrate South African higher education institutions with their global counterparts, and this trend, in turn, triggered an avalanche of reports (such as, to name a few, the Green Paper on Higher Education Transformation, 1996; A Programme for the Transformation of Higher Education, 1997; the Higher Education Act 101 of 1997; the National Plan for Higher Education, 2001; the Regulations and Manual for Annual Reporting of Higher Education Institutions, 2001, 2003 and 2007; and the Research and Policy Report on Governance in South African Higher Education, 2002) (Marx, 2007; Wolhurter, Van der Walt, Higgs \& Higgs, 2007). According to the CHE (2000) as well as Smout and Stephenson (2002), the objective with restructuring the higher education landscape was to achieve an integrated, unified higher education system based on the principles of equity, democratisation, quality, academic freedom, institutional autonomy, effectiveness and efficiency. This was further supported by the "The National Plan for Higher Education", which set out the purposes of higher education as being: human resource development, high-level skills training and the production, acquisition and application of new knowledge (CHE, 2009a; CHE, 2010b).

A new government department responsible for higher education, the DoHET, was created by 
Parliament in 2009, and this presented an opportunity for universities to redefine their role and to look for mechanisms that would support diversity, appropriate governance, funding and quality assurance (CHE, 2009a). Currently, South Africa's higher education system consists of 23 public HEls, which according to the CHE (2010a) enrolled 799490 students (653 398 undergraduate students and 118622 postgraduate students) and produced 133241 qualifications at all levels, including 7514 master's and 1182 doctoral degrees in 2008 (CHE, 2010a).

\subsection{Governance at South African HEls}

The underlying philosophy that $\mathrm{HEls}$ are commodities, and that students, society and business are customers, prevails in South Africa (Grundling \& Steynberg, 2008). HEls in South Africa are regulated by the Higher Education Act 101 of 1997 (RSA, 1997), the Regulations of the Act of 2003 and 2007 (RSA, 2003; 2007) and the Implementation Manual for Annual Reporting by Higher Education Institutions (hereafter referred to as the reporting manual) issued by the Department of Education under the regulations of the Act (DOE, 2007).

South African HEls are governed by their respective councils, subject to the Higher Education Act and their own institutional statute (RSA, 1997). As such, councils are their highest decisionmaking body, responsible for the governance, quality, integrity, financial affairs, performance and reputation of each institution. The council structure is determined by section 27 of the Higher Education Act, with various committees of council elected under section 29 (RSA, 1997). The Institutional Forum is one of those committees of council that is required in terms of section 31 of the Higher Education Act (RSA,1997) to advise council broadly on issues affecting the institution. It specifically directs its attention to the areas of implementation of legislation and national policy; race and gender equity; the selection of candidates for senior management positions; codes of conduct, mediation and dispute resolution; and the fostering of an institutional culture (Hall et al., 2002:20). The other committees of council include, inter alia, audit, remuneration and finance committees (RSA, 1997). A further key governance component of $\mathrm{HEls}$ is the senate, with its subsidiary structures, of which the principal is the faculty boards. Senate is accountable to council for the academic and research functions of the $H \varepsilon l$, and must further perform other functions delegated to it by council (RSA, 1997; Hall et al., 2002:20). The Institutional Statute determines that the principal (vice-chancellor and rector) is the (EO of the $\mathrm{HEl}$ and responsible for the day-to-day management and administration of the $\mathrm{HEl}$ (Hall et al., 2002; Marx, 2007; PricewaterhouseCoopers, 2009).

Annual reporting by HEls is governed by the Higher Education Act 101 of 1997 (RSA, 1997), the Regulations of the Act of 2003 and 2007 (RSA, 1997; 2003; 2007) and the reporting manual (DOE, 2007). The reporting manual's guidelines are based on King II (IOD, 2002), which in turn requires disclosure on aspects of boards and directors (meaning council and council members), risk management, internal audit, integrated sustainability reporting, accounting and auditing, and compliance and enforcement of laws and regulations (IOD, 2002). The manual further requires specific disclosures regarding the $\mathrm{HEl}$ corporate governance of council, including that of the composition of council and its committees (D0E, 2007; Hall et al., 2002; Marx, 2007). It is also of interest to note that King III, which became effective on 1 March 2010, applies to all entities, including $\mathrm{HEls}$, and will probably result in a revised reporting manual (IOD, 2010). 


\section{RESEARCH METHODOLOGY}

In order to determine the amount and the extent of information disclosed in each section and to decide if an $\mathrm{HEl}$ has fully disclosed, not disclosed or obscurely disclosed the required corporate governance information in its annual report, the empirical method known as "content analysis" was utilised. Further to the discussion in section 2, Berelson (1952), Krippendorff (1980) and Weber (1990) all agree that content analysis is a systematic, replicable technique for compressing many words of text into fewer content categories based on explicit rules of coding. For Ingram and Frazier (1980), the methodology of content analysis involves the selection of analytical categories within the context of the content material. Stemler (2001) believes that in order to allow for replication, the content analysis technique can be applied only to data that is durable in nature. Mouton (2005) agrees with Stemler (2001), and goes on to state that content analysis is a study that analyses the content of texts or documents such as letters, speeches and annual reports.

For the purpose of coding the HEls' annual reports, the following guidelines were used.

\section{CONTENT ANALYSIS GUIDELINES}

\begin{tabular}{|c|c|c|c|}
\hline & FULLY DISCLOSED & NOT DISCLOSED & OBSCURELY DISCLOSED \\
\hline Guideline & $\begin{array}{l}\text { If the required information is } \\
\text { disclosed under its category } \\
\text { in a paragraph, a few } \\
\text { paragraphs or a full page and } \\
\text { this information contains all } \\
\text { the required information as } \\
\text { well as voluntary disclosures } \\
\text { for that category, the item is } \\
\text { marked as yes in the } \\
\text { checklist. }\end{array}$ & $\begin{array}{l}\text { If there is no disclosure at all } \\
\text { of the minimum required } \\
\text { information, the item is } \\
\text { marked as No in the } \\
\text { checklist. }\end{array}$ & $\begin{array}{l}\text { If the minimum required } \\
\text { information is disclosed, but } \\
\text { is not disclosed separately } \\
\text { under its category, and is not } \\
\text { disclosed in detail (i.e. it } \\
\text { appears in one sentence that } \\
\text { does not give adequate } \\
\text { details), the item is marked } \\
\text { as Obscure in the checklist. }\end{array}$ \\
\hline
\end{tabular}

\section{RESEARCH FINDINGS AND INTERPRETATION}

The research findings present the results of content analyses performed on 22 annual reports, which were analysed for their disclosure of corporate governance information in their annual reports. As explained in section 2, one of the 23 public HEls in South Africa is not represented here, as its annual report was not submitted to the DoHET and thus it is not part of the analyses.

Table 1 shows the categories and disclosed topics (number 1 to 21 ) relating to the council, its meetings and members and their responsibilities and roles, which were reviewed during the content analysis. It revealed that both the name and independence of the chairperson of the council of the participating $\mathrm{HEls}$ were fully disclosed in their annual reports, while none of them disclosed the fact that the independence of the chairperson of the council is regularly evaluated, and only one of the participating $\mathrm{HEls}$ disclosed background information of the chairperson or noted that the chairperson's performance is regularly evaluated by the other members of council. 
TABLE 1: Council, its members, meetings and responsibilities and roles

\begin{tabular}{|c|c|c|c|c|c|}
\hline $\mathrm{Nr}$ & Category and disclosed item & yes & No & Obscure & Total \\
\hline \multicolumn{6}{|c|}{ Council chairperson } \\
\hline 1 & Name of chairperson & 22 & 0 & 0 & 22 \\
\hline 2 & Independence of the chairperson & 22 & 0 & 0 & 22 \\
\hline 3 & Background of the chairperson & 1 & 18 & 3 & 22 \\
\hline 4 & $\begin{array}{l}\text { Regular evaluation of the independence of the } \\
\text { chairperson }\end{array}$ & 0 & 22 & 0 & 22 \\
\hline 5 & $\begin{array}{l}\text { Chairperson's performance is evaluated by council } \\
\text { members }\end{array}$ & 1 & 21 & 0 & 22 \\
\hline \multicolumn{6}{|c|}{ Other members of council } \\
\hline 6 & Independent non-executive members & 21 & 1 & 0 & 22 \\
\hline 7 & Executive members & 21 & 1 & 0 & 22 \\
\hline 8 & Student and employee members & 20 & 1 & 1 & 22 \\
\hline 9 & Non-executive members (not independent) & 21 & 1 & 0 & 22 \\
\hline 10 & Qualifications of members of council & 4 & 17 & 1 & 22 \\
\hline 11 & Experience (in years) of members of council & 0 & 20 & 2 & 22 \\
\hline 12 & Regular evaluation of council's performance & 6 & 16 & 0 & 22 \\
\hline 13 & Formal induction/orientation for members & 3 & 19 & 0 & 22 \\
\hline \multicolumn{6}{|c|}{ Council meetings } \\
\hline 14 & Number of meetings & 15 & 6 & 1 & 22 \\
\hline 15 & Attendance of meetings & 18 & 4 & 0 & 22 \\
\hline \multicolumn{6}{|c|}{ Council roles and responsibilities } \\
\hline 16 & $\begin{array}{l}\text { Council retains full and effective control over the } \\
\text { institution }\end{array}$ & 1 & 21 & 0 & 22 \\
\hline 17 & $\begin{array}{l}\text { Council members have a right to obtain professional } \\
\text { advice }\end{array}$ & 0 & 22 & 0 & 22 \\
\hline 18 & $\begin{array}{l}\text { Council members have a right to retain certain powers } \\
\text { to themselves while delegating others }\end{array}$ & 0 & 22 & 0 & 22 \\
\hline 19 & $\begin{array}{l}\text { Council members consider and assess the going } \\
\text { concern status of the } \mathrm{HEl}\end{array}$ & 0 & 3 & 19 & 22 \\
\hline 20 & Council has unrestricted access to information & 0 & 3 & 19 & 22 \\
\hline 21 & Remuneration of council members & 10 & 12 & 0 & 22 \\
\hline
\end{tabular}

Source: Annual report disclosure

None of the participating $\mathrm{HEls}$ disclosed that council members have the right to obtain professional advice or to retain powers whilst delegating others, and only one of the participating $\mathrm{HEls}$ disclosed that the council retains full and effective control over the $\mathrm{HEl}$.

Of the 21 disclosed topics reviewed, only two instances were identified where the disclosures of the majority of the participating $\mathrm{HEls}$ were regarded as obscure. These related to the disclosures of councils' consideration and assessment of the going concern status of their $\mathrm{HEls}$, and the right of council to have unrestricted access to information.

Given the results displayed in Table 1, it is clear that generally disclosures relating to the council, its meetings and members and their responsibilities and roles could be improved. In six 
instances (disclosed topics 4, 11, 17, 18, 19 and 20), the disclosures were deemed not to provide the required information, while in five instances (disclosed topics 3, 5, 10, 13 and 16) fewer than five participating $\mathrm{HEls}$ fully met the disclosure requirements, bringing the number of disclosed topics deemed not to be fully compliant to $11(6+5)$ of the 21 .

TABLE 2: Council committees, internal and external audit, other issues and other governance structures

\begin{tabular}{|c|c|c|c|c|c|}
\hline $\mathrm{Nr}$ & Category and disclosed item & yes & No & Obscure & Total \\
\hline \multicolumn{6}{|c|}{ Council committees } \\
\hline 1 & Audit committee & 21 & 1 & 0 & 22 \\
\hline 2 & Finance committee & 19 & 3 & 0 & 22 \\
\hline 3 & Risk committee & 15 & 7 & 3 & 22 \\
\hline 4 & Human resources committee & 19 & 3 & 0 & 22 \\
\hline 5 & Other committee & 18 & 4 & 0 & 22 \\
\hline \multicolumn{6}{|c|}{ Internal audit and external audit } \\
\hline 6 & Existence of an internal audit function & 19 & 3 & 0 & 22 \\
\hline 7 & $\begin{array}{l}\text { Internal audit function has unrestricted access to the } \\
\text { audit committee }\end{array}$ & 18 & 4 & 0 & 22 \\
\hline 8 & Internal audit function is outsourced & 7 & 9 & 6 & 22 \\
\hline 9 & Internal audit function is in-house & 6 & 10 & 6 & 22 \\
\hline 10 & $\begin{array}{l}\text { Internal audit function have a clear charter and } \\
\text { mandate }\end{array}$ & 9 & 7 & 6 & 22 \\
\hline 11 & Internal auditors collaborate with external auditors & 1 & 18 & 3 & 22 \\
\hline 12 & $\begin{array}{l}\text { External auditors have unrestricted access to the } \\
\text { council }\end{array}$ & 4 & 4 & 14 & 22 \\
\hline 13 & $\begin{array}{l}\text { External audit is performed by one of the "big 4" } \\
\text { auditing firms }\end{array}$ & 22 & 0 & 0 & 22 \\
\hline 14 & $\begin{array}{l}\text { External audit is not performed by one of the "big 4" } \\
\text { auditing firms }\end{array}$ & 2 & 20 & 0 & 22 \\
\hline \multicolumn{6}{|c|}{ Other issues and other governance structures } \\
\hline 15 & Environmental issues & 2 & 18 & 2 & 22 \\
\hline 16 & Social issues & 12 & 10 & 0 & 22 \\
\hline 17 & Ethical issues & 14 & 7 & 1 & 22 \\
\hline 18 & Senate & 19 & 3 & 0 & 22 \\
\hline 19 & Institutional Forum & 20 & 2 & 0 & 22 \\
\hline 20 & Reference to King III & 3 & 19 & 0 & 22 \\
\hline
\end{tabular}

Source: Annual report disclosure

Table 2 shows the categories and disclosed topics (number 1 to 20) relating to the council committees, internal and external audit, environmental, social and ethical issues, King III reference and other governance structures (senate and institutional forum).

All of the participating HEls made use of one of the "big 4" accounting and auditing firms as external auditors, and all of them fully disclosed this fact. Two instances were noted where universities used one of the "big 4" in conjunction with the "other audit firms". It was further noted that 14 of the participating $\mathrm{HEls}$ obscurely disclosed the fact that their external auditors 
have access to council, and four participating HEls did not disclose the fact at all. Only one of the participating $\mathrm{HEls}$ disclosed fully that its internal auditors could collaborate with its external auditors.

Taking into account the requirements for full disclosure of the study, it would appear that only 19 of the 22 participating $\mathrm{HEls}$ have an internal audit function (and 18 of these $19 \mathrm{HEls}$ disclosed fully that their internal audit functions have unrestricted access to their audit committees), and this is performed in-house at six of the participating $\mathrm{HEls}$. This function was outsourced by seven others, while for six of the HEls such information was obscurely disclosed. The literature supports the view that both internal and external auditors play important roles in organisational governance (Archambeault, DeZoort \& Holt, 2008:376; Sarens, 2009:2), and annual report users should be informed of this. Taking the above results of the study into account, it appears that the importance of both external and internal audit as a governance mechanism has not been fully disclosed in the annual reports of the participating $\mathrm{HEls}$ and could be improved.

In contrast, disclosures about the council committees appeared to be more comprehensive. Only one of the participating $\mathrm{HEls}$ did not fully disclose particulars of its audit committee, while this was the case for three participating $\mathrm{HEls}$ with regard to their finance and human resources committee. In relation to risk committee disclosures, seven of the participating $\mathrm{HEls}$ did not fully disclose the required information. None of the information disclosed on council committees was assessed as being obscure.

The disclosure relating to other aspects (environmental, social and ethical issues) and reference to the impact of the King III report varied. The study found that 18 out of the 22 participating $\mathrm{HEls}$ did not disclose information relating to environmental matters, while for social and ethical matters ten and seven participating $\mathrm{HEls}$ refrained from disclosure. Only three participating HEls fully disclosed that the implications of the King III report are being considered. As anticipated from HEls' disclosures on the more traditional university governance structures, the senate and the institutional forum received a great deal of attention in HEls' annual reports: for 19 and 20 participating $\mathrm{HEls}$ such disclosures were deemed to be fully compliant.

\section{CONCLUSION AND AREAS FOR FUTURE RESEARCH}

In conclusion, the paper found that the higher education environment has become more demanding over the years, resulting in HEls currently facing many challenges. This in turn has given rise to the need for sound management of these institutions and adherence to sound governance practices, which are becoming increasingly aligned with corporate governance practices followed in the business environment. The study found that according to the corporate governance disclosures in the annual reports, $\mathrm{HEls}$ in South Africa have established corporate governance structures that appear to be functioning. Of concern, however, were the findings that disclosures on such structures often lack detail on the actual practices applied and corporate governance performance, thus casting doubt on the true state of affairs at these institutions. Information on the chairperson of the council - his/her independence, background information, evaluation practices, and rights to obtain professional advice, retain powers or delegate others - was fully disclosed by a small number of participating $\mathrm{HEls}$ in their annual reports. The importance of internal audit and external audit as governance mechanisms serves as another example of detailed information not disclosed by nearly all the $\mathrm{HEls}$ in their annual reports. 
The majority of $\mathrm{HEls}$, furthermore, failed to disclose information on environmental matters, which will form part of the integrated reporting required by King III. Only two participating HEls disclosed in their annual reports that they are considering the implications of King III. These findings indicate that $\mathrm{HEls}$ still have a long way to go to ensure that the requirements of King III will be met in future.

The study was performed prior to the implementation of King III, and it is recommended that an analysis similar to the one undertaken here should be performed after King III becomes effective. This should be done to assess the impact of King III on the corporate governance practices and disclosures of $\mathrm{HEls}$ in South Africa. Another area for future research is to determine how the values of the academics in South African HEls have been affected by institutional changes - changes that have resulted in national drives for efficiency and productivity, and that have triggered the adoption of business-orientated corporate governance practices.

\section{LIST OF REFERENCES}

Abeysekera, I. (2007). Intellectual capital reporting between a developing and developed nation. Journal of Intellectual Capital, 8(2), pp. 329-345.

Archambeault, A.S., DeZoort, F.T., Holt, T.P. (2008). The need for an internal auditor report to external stakeholders to improve governance transparency. Accounting Horizons, 22(4), pp. 375-388.

Arnold, ع. (2006). Facilitating university sustainability through decision-orientated financial reporting. Unpublished mini-thesis in partial fulfilment of the degree M Education. Cape Town: University of the Western Cape.

Barac, K. \& Moloi, T. (2010). Assessment of corporate governance reporting in the annual reports of South African listed companies. The South African Journal of Accountability and Auditing Research, 10(1), pp. 19-28.

Bargh, C., Scott, P. \& Smith, D. (1996). Governing universities: changing the culture? Ballmoor: Open University Press.

Belloc, B. (2003). Incentives and accountability: Instruments of change in higher education. Higher Education Management and Policy, 15(1), pp. 23-41.

Brennan, N. \& Solomon, J. (2008). Corporate governance, accountability and mechanisms of accountability: an overview. Accounting, Auditing \& Accountability, 21(7), pp. 885-906.

Boesso, G., Kumar, K. (2007). Drivers of corporate voluntarily disclosure: A framework and empirical evidence from Italy and the United States. Accounting, Auditing and Accountability Journal, 20(2), pp. 269-296.

Cadbury Report. (1992). Report of the Committee on the Financial Aspects of Corporate Governance. London: Gee \& Company Ltd.

Considine, M. (2000). APSA Presidential Address 2000. The Tragedy of the Common-rooms? Political Science and the New University Governance. Australian Journal of Political Science, 36, pp. 145-156.

Council for Higher Education. (CHE). (2000). Shape and Size of Higher Education Task Team. Towards a New Higher education Landscape: Meeting the equity, quality and social imperatives of South Africa in the $21^{\text {st }}$ century. Pretoria: South Africa. 
Council for Higher Education. (CHE). (2009a). Report of the Council on Higher Education's

Consultative Conference, 2009. [0n-line] Available from:

http://www.che.org.za/documents/d000203/. (Accessed 15 October 2010).

Council for Higher Education. (CHE). (2009b). The Response of the Council on Higher Education to the report of the Ministerial Committee on Transformation and Social Cohesion and the Elimination of Discrimination in Public Higher Education Institutions. [On-line] Available from:

http://www.che.org.za/documents/d000202/. (Accessed 15 October 2010).

Council for Higher Education. (CHE). (2009c). The State of Higher Education in South Africa. Higher Education Monitor, 8, 0ctober 2009. CHE: Pretoria.

Council for Higher Education. (CHE). (2010a). Higher Education in South Africa. [On-line] Available from: http://www.che.org.za/heinsa/. (Accessed 21 0ctober 2010).

Council for Higher Education. (CHE) (2010b). Community Engagement in South Africa Higher

Education. [On-line] Available from: http://www.che.org.za/documents/d00204/. (Accessed 10 October 2010).

Davis, G. (2005). New directions in corporate governance. AR Reviews in Advance, 18(9), pp. 8.1-8.20.

De Boer, H. \&. Goedegebuure, L. (2007). "Modern” governance and codes of conduct in Dutch higher education. Higher Education Research \& Development, 26(1), pp. 45-55.

De Groof, J.D., Neave, G. \& Svec, J. (1998). Democracy and Governance in Higher Education.

Legislative Reform Programme for Higher Education and Research Council of Europe. The Hague:

Kluwer Law International.

Department of Education (DOE). (2007). Implementation Manual for Annual Reporting by Higher Education Institutions (second volume). Pretoria: Department of Education.

Doost, R.K. (1998). Financial accountability: a missing link in university financial reporting systems. Managerial Auditing Journal, 13(8), pp. 479-488.

Enders, J. (2004). Higher education internationalisation and the nation-state: recent developments in governance theory. Higher Education, 47, pp. 361-382.

Geuna, A. \& Muscio, A. (2009). The Governance of University Knowledge Transfer: A Critical Review of the Literature. Minerva, 47(1), pp. 93-114.

Goedegebuure, L. \&. Hayden, M. (2007). Overview: Governance in higher education - concepts and issues. Higher Education Research \& Development, 26(1), pp. 1-11.

Grundling, J.P. \& Steynberg, L. (2008). Academic entrepreneurship in South African HEls. Industry \& Higher Education, 22(1), pp. 9-17.

Hall, M., Symes, A. \& Luescher, T.M. (2002). Governance in South African Higher Education: (Research Report Prepared For The Council Of Higher Education). CHE: South Africa.

Harman, G. (2002). Academic leaders or corporate managers: deans and heads in Australian higher education, 1977 to 1997. Higher Education Management and Policy, 14(2) pp. 53-70.

Harman, K. \& Treadgold, $\varepsilon$. (2007). Changing patterns of governance for Australian universities. Higher Education Research \& Development, 26(1), pp. 13-29.

Henkel, M. (1997). Academic values and the university as corporate enterprise. Higher Education Quarterly, 151(2), pp. 134-143. 
Huisman, J. \& Currie, J. (2004). Accountability in higher education: bridge over troubled water. Higher Education, 48, pp. 529-551.

Ingram, R.W. \& Frazier, K.B. 1980. Environmental performance and corporate disclosure. Journal of Accounting Research, 18(2), pp. 614-622.

Institute of Directors. (IOD). (2002). (King II Report on Corporate Governance), Institute of Directors in Southern Africa: Johannesburg.

Institute of Directors. (IoD). (2009). (King Report on Corporate Governance for South Africa). Institute of Directors in Southern Africa: Johannesburg.

Kennedy, K.J. (2003). Higher education governance as a key policy in the 21 st century. Educational Research for Policy and Practice, (2), pp. 55-70.

Kezar, A. \& Eckel, P. D. ( 2004). Meeting today's governance Challenges: a synthesis of the literature and examination of a future agenda for scholarship. The Journal of Higher Education, 75(4), pp. 371399.

Krippendorff, K. (1980). Content Analysis: An Introduction to its Methodology. Newbury Park CA: Sage. Küpper, H. (2003). Management mechanisms and financing of higher education in Germany. Higher Education Management and Policy, 15(1), pp. 71-89.

Lazaretti, L. \& Tavoletti, S. (2006). Governance shifts in higher education: a cross-national comparison. European Educational Reserach Journal, 5(1), pp. 18-37.

Marx, B. (2007). Corporate Governance Practices at Higher Education Institutions in South Africa. Journal of Economic and Financial Sciences, 1(2), pp. 105-122.

Middlehurst, R. (2004). Changing internal governance: a discussion of leadership roles and management structures in UK universities. Higher Education Quaterly, 58(4), pp. 258-279.

Mills, M.R. (2007). Stories of politics and policy: Florida's higher education governance reorganization. The Journal of Higher Education, 78(2), pp. 162-189.

Mir, M.Z. \& Rahaman, A.S. (2003). The role of accounting in the enterprise bargaining process of an Auditalian university. Accounting, Auditing \& Accountability Journal, 16(3), pp. 298-315.

Mok, K. (2003). Globalism and higher education restructuring in Hong Kong, Tawain and Mainland China. Higher Education Research \& Development, 22(2), pp. 117-129.

Mouton, J. (2005). How to succeed in your master's and doctoral studies. A South African guide and resource book. Pretoria: Van Schaik.

Newby, H. (2003). The management of change in higher education, Higher Education Management and Policy, 15(1), pp. 9-22.

Peterson, M.W. (1986). Ashe Reader on Organization and Governance in Higher Education. Ashe Rader Series. 3rd edition. Lexington, Massachusetts: Ginn Press.

Ponnu, C.H. \& Ramthandin, S. (2008). Governance and performance: publically listed companies in Malaysia. Journal of Business Systems, Governance and Ethics, 3(1), pp. 35-53.

Pope, M.L. (2004). A conceptual framework of faculty trust and participation in governance. New Direction for Higher Education, 127, pp. 75-84.

PricewaterhouseCoopers. (2009). King's Councel: King III - a higher education perspective. Corporate Governance Series. South Africa. 
Republic of South Africa (RSA). (1997). Higher Education Act No 101 of 1997. Government Gazette No 18515, Notice 1655, 19 December 1997. Pretoria: Government Printers.

Republic of South Africa (RSA). (2003). Regulations for Annual Reporting by Higher Education Institutions. Government Gazette No 25407, Volume 458, August 2003. Pretoria: Government Printers.

Republic of South Africa (RSA). (2007). Regulations for Annual Reporting by Higher Education Institutions. Government Gazette No 30132, 01 August 2007. Pretoria: Government Printers.

Salter, B. \& Tapper, T. (2002). The external pressures on the internal governance of universities. Higher Education Quaterly, 56(3), pp. 245-256.

Sarens G (2009). Internal auditing research: Where are we going? Editorial. International Journal of Auditing, 13, pp. 1-7.

Shattock, M. (2004). The Lambert Code: Can We Define Best Practice. Higher education Quarterly, 58(4) pp. 229-242.

Skærbæk, P. (2005). Annual reports as interaction devices: the hidden constructions of mediated communication. Financial Accountability \& Management, 21(4) pp. 385-411.

Smout, M \& Stephenson, S. (2002). Quality Assurance in South African Higher Education: a new beginning. Quality in Higher Education, 8(2) pp. 197-206.

Steccolini, I. (2004). Is the annual report an accountability medium? An empirical investigation into Italian local governments. Financial Accountability \& Management, 20(3), pp. 327-350.

Stemler, S. (2001). An overview of content analysis. Practical Assessment, Research \& Evaluation, 7(17). [On-line] Available: http://PAREonline.net/getvn.asp?v=7\&n=17. (Accessed 16 February 2011).

Taylor, J. (2003). Sticks and carrot: The effectiveness of government policy on higher education in England since 1979. Higher Education Managment and Policy, 15(1), pp. 91-103.

Unerman, J. (2000). Methodological issues - Reflections on quantification in corporate social reporting content analysis. Accounting, Auditing \& Accountability Journal, 13(5), pp. 667-681.

Vaira, M. (2004). Globalisation and higher education organizational change: a framework for analysis. Higher Education, 48, pp. 483-510.

Weber, R.P. (1990). Basic Content Analysis, 2nd ed. Newbury Park: California.

Wolhurter, C., Van der Walt, H., Higgs, L. \& Higgs, P. (2007). Die akademiese professie in Suid-Afrika se belewing van die huidige rekonstruksie van die samelewing en die hoër onderwys. Tydskrif vir Geesteswetenskappe, 47(4), pp. 501-515. 
CORPORATE GOVERNANCE PRACTICES AT SOUTH AFRICAN HIGHER EDUCATION INSTITUTIONS 